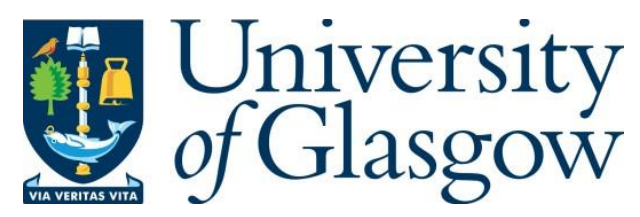

Torrance, D. and Forde, C. (2017) Redefining what it means to be a teacher through professional standards: implications for continuing teacher education. European Journal of Teacher Education, 40(1), pp. 110-126.

There may be differences between this version and the published version. You are advised to consult the publisher's version if you wish to cite from it.

http://eprints.gla.ac.uk/144705/

Deposited on: 7 September 2017

Enlighten - Research publications by members of the University of Glasgow http://eprints.gla.ac.uk 


\title{
Redefining What It Means To Be A Teacher Through Professional Standards: Implications For Continuing Teacher Education
}

\author{
Deirdre Torrance, University of Edinburgh, UK and Christine Forde, University of Glasgow, UK
}

\begin{abstract}
This article connects with an international debate around the place of professional standards in educational policy targeted at enhancing teacher quality, with associated implications for continuing teacher education. Scotland provides a fertile context for discussion, having developed sets of professional standards in response to a recent national review of career-long teacher education. That review called for a reprofessionalisation of the teaching profession and the revision of the standards was an element of this process. Scotland is utilised as a lens through which one country's response to international trends is viewed, with a focus on 'teacher leadership' and 'practitioner enquiry' as policy endorsed sets of practices. The analysis demonstrates the complex and contested nature of these terms and the tensions posed between the need to meet professional standards as part of teacher education and aspirational dimensions of the current policy project of reprofessionalisation. The article concludes by considering the implications for continuing teacher education.
\end{abstract}

Key Words: professional standards, teacher leadership, practitioner enquiry, continuing teacher education, career long professional learning

\section{Introduction}

Internationally, a key driver behind education policy is the search for 'effective practice' that will improve pupil attainment outcomes (OECD 2012). As part of the programme of reform in Scottish education, the Scottish Government commissioned a review of teacher education, Teaching Scotland's Future (TSF) (2011). Among the recommendations of TSF was a 'reprofessionalisation' of the teaching profession. A comprehensive revision of the sets of professional standards for teachers formed a strategic element of this process, in which the standards were used as texts in which policy intentions (Taylor 1997) were encoded as part of the wider project of up-skilling the teaching profession. The expectations contained within the revised standards were designed to support a process of redefining the role of the teacher to reflect wider expectations and demands: "...to help teachers develop and improve in a planned way which reflects their growing expertise and their ability to work effectively in different contexts" (Donaldson 2011, 9). One of the explicit aims of the revision process was to enhance the continuity and coherence of statements across all of the Standards (GTCS 2011). Thus, in 2012, The General Teaching Council for Scotland (GTCS) published revised professional standards with a view to create a suite of standards covering the significant phases of a teaching career: initial preparation and induction into the profession; career long teacher development; leadership and management which included a revised Standard for Headship and the new Standards for Middle Leadership and Management (GTCS 2012 a,b,c). That continuity and coherence was supported by a conscious decision to underpin the revised professional standards with new expectations for all teachers in Scotland (GTCS 2011). In addition to the expectations around classroom teaching and management, curriculum development and delivery, all teachers regardless of their role, are now expected to embrace the practices of 'teacher leadership' and 'practitioner enquiry'. By giving those aspects greater emphasis, there is a future orientation in these standards that privileges the contribution of teachers and leaders to realising the wider policy intention of improved outcomes for pupils. We use Scotland as a case study to explore some of the tensions inherent in using standards as policy tools where complex ideas are reduced to sets of competencies, and to consider the implications for continuing teacher education. 
The article reports on one strand of a larger investigation of the use of standards as policy texts in a system wide reform programme in Scotland. The article begins with an overview of the study and then uses the literature to raise issues about the purpose and design of standards in relation to the continuing professional learning of teachers across their career. The focus then turns to the two themes of 'teacher leadership' and 'practitioner enquiry', drawing from the expanding literature to examine the conceptualisation of each term within these standards. As the professional standards for teaching used in Scottish education have a regulatory function as well as being perceived as significant tools in professional learning, there is a need to surface and examine critically the underpinning assumptions of these texts. The analysis highlights some of the tensions and gaps in the construction of these two concepts, particularly around the balance between aspiration and regulation. The article suggests that if the new conceptualisations of practitioner enquiry and teacher leadership are to become a reality in professional practice then, through career long professional learning, teachers need to be able to engage with professional standards as discursive texts and explore in their practice ways of realising these ideas.

\section{Standards for Teaching}

Professional standards can be construed as one element in the policy 'technologies', the tools, artifacts and practices used in the process of teacher workforce development as part of a wider policy drive for improvement (CEPPE 2013) for example in Australia (AITSL 2011) and New Zealand (EC 2013). This is the case in Scotland, where professional standards are a significant and established element in educational policy. Various teacher standards have existed in Scotland since 2000; for Initial Teacher Education, Full Registration, Chartered Teacher and Headship (O'Brien 2011). One of the functions of the General Teaching Council for Scotland as the policy guardian of those standards is:

to establish (and to review and change as necessary) -

(i) the standards of education and training appropriate to school teachers;

(ii) the standards of conduct and professional competence expected of a registered teacher

(Scottish Parliament 2011).

The revision of the standards was against a backdrop of considerable policy discussions about the teaching profession and teacher development. The process of revision set up by the GTCS followed the well-established pattern of consensus building used in Scottish policy development through which endorsed policy actors (Johnston and MacKenzie 2003) were invited to participate in the development process. Working groups included serving teachers (including chartered teachers), headteachers, Local Authority officers and university teacher educators who had been previously supportive of teacher development. These working groups produced draft sets of standards, which were ratified by the Council where the teacher unions represent a significant element of the membership. The General Teaching Council began work on the revision of the standards at the point at which the Chartered Teacher programme was suspended following a second review by the Scottish Government, Advancing Professionalism (McCormac 2011) on the teachers' contract and conditions of service. This report took a more critical stance on teacher development including the limited impact of the Chartered Teacher programme (designed to develop and reward accomplished practice) (Reeves and Fox 2008). In the review the GTCS therefore had to consider how teachers' practice could be set in a developmental sequence from initial teacher education (Standard for Provisional Registration, GTCS 2012a), the one-year induction programme (Standard for Full Registration, GTCS 2012a) to the ongoing development of experienced teachers (Standard for Career-Long Professional Learning, GTCS 2012b).

In Scotland, the revision of the full suite of professional standards was an important strategy in the implementation of TSF (Donaldson 2011). A specific intention of this programme of reforms has been a process of 'reprofessionalisation' to promote a form of "extended professionalism" (Donaldson 2011, 15). In TSF, the vision of extended professionalism is presented: 
This review endorses the vision of teachers as increasingly expert practitioners whose professional practice and relationships are rooted in strong values, who take responsibility for their own development and who are developing their capacity both to use and contribute to the collective understanding of the teaching and learning process (Donaldson 2011, 16).

The process of 'reprofessionalisation' to attract and retain teachers is now a consistent theme in international policy (OECD 2015) but this is not as straightforward as the policy discourse would suggest. There are substantial debates about reprofessionalisation, perceived to enhance professional agency or alternatively as deprofessionalisation to ensure compliance with externally mandated policies in schools and classrooms, which results in a narrowing of the scope of professional decision-making and practice. This policy intention of reprofessionalisation in Scotland to increase teacher agency could be seen as constructive in reclaiming an extended professionalism (Hoyle 1995, Stenhouse 1975). However, there are concerns that reprofessionalisation is about determining professional practice within the confines of current policy demands. A significant concern is the policy codification is based on a reductive model where teaching is formulated as a routinized process whereby teachers are increasingly deskilled (MacBeath 2012). Stillman and Anderson (2015) perceive one of the central tensions being where policy mandates clash with teachers' beliefs and expertise. It is important, therefore, to examine critically the underpinning constructions of what it means to be a teacher in policies, particularly the sets of professional standards, which in Scottish education are presented as furthering a reprofessionalisation agenda.

Standards are intended to promote consistency of practice across diverse educational settings in an educational system as well as providing a means to make judgments about the quality of practice in different places (Fenwick 2010). Therefore, standards can exert a powerful influence through an educational system. Ceulemans et al. (2012) track professional standards in teacher education in the Netherlands and illustrate how standards shape processes such as the curriculum and assessment. One of the criticisms is that professional standards put forward a reductive model where teaching is seen as an instrumental process and so professional practice is reduced to a narrow set of behaviours. For example, Teachers' Standards (DfE 2011) in England identify the sets of behaviours and teaching is characterized largely as curriculum delivery. Kennedy (2005) argues that professional standards constrain teachers, denying them the opportunity to generate their own narratives of what it means to be a teacher and overlooking the moral dimensions of education while Tuinamuana (2011) raises concerns about standards advancing increased expectations and accountability processes. Gronn (2000) argues that particular understandings are inscribed in standards while other understandings may be invisible in the official codification.

Standards can also have a developmental function, being tools for self-evaluation by individual practitioners (Reeves et al. 1998) or forming part of a system-wide strategy for professional learning (Kleinhenz and Ingvarson 2007). Sachs (2003) cautions against the use of standards as a government-imposed regulatory framework, promoting one particular view of teaching. She argues teaching standards have multiple purposes: summarising commonsense understandings of practice; quality assurance criteria; as developmental tools; and as a means of certification and accreditation. Standards might also help crystallize different and more expansive constructions of professional practice (Christie and Kirkwood 2006). Indeed, Darling-Hammond (1999, 28) sees the National Board Teaching Standards in the USA, as the means for leveraging change because "the standards offer a conception of teaching that is linked to student learning". As such construction of teaching underpinning a particular set of professional standards is important in the development and use of standards. 
There can be significant tensions where standards are expected to perform different functions and so the balance between aspiration and regulation is one competing dimension of professional standards, with associated implications for continuing teacher education. The professional standards for teaching in Scotland make an interesting case study, given the more elaborated construction which includes professional values, knowledge, personal qualities and actions. Similar to the sets of Australian professional standards for teaching (AITSL, 2011), the Scottish standards provide a career-long development framework. Further, the Scottish standards stand in contrast to some of the more concise standards such as the English Teachers' Standards (DfE 2011) and the Practising Teacher Criteria in New Zealand (EC 2013). These standards articulate a basic level of competence needed to practice but do not include an extended or wider role as teachers progress in their careers. Nevertheless the professional standards for teaching in Scotland are technical documents. Their concise design restricts extended definition and exemplification of revised constructions of professional practice. As such, these standards are not designed to discuss the complexities of practice realities (Forde et al. 2015). Professional standards present unproblematically key concepts, which have to be understood and then enacted in practice. This article seeks to probe two key concepts embedded in two sets of professional standards and considers the implications for continuing teacher education.

\section{Analysis of Teaching Standards}

Two sets of standards for teaching in Scottish education were analysed: the Standards for Registration (SfFR) (GTCS 2012a) and the Standard for Career-Long Professional Learning (SfCPL) (GTCS, 2012b). A critical policy analysis approach (Taylor 1997) was used to examine the SfFR and the SfCPL as policy tools intended to bring about change and improvement. Trowler (1998 cited in Nudzor 2009) identifies an 'encoding' stage, that is the formulation of policy and a 'decoding stage', that is the implementation process and argues that in both, the contested nature of policy is apparent. In this study, we recognise that the relationship between formulation and implementation is complex but argue that interrogation of the professional standards as policy documents and texts in which policy intentions (Taylor 1997) are encoded is a necessary component of the policy project of 'reprofessionalisation'. Here we examine policy texts, "as the expression of official purpose or statements of the courses of action that policy makers and administrators are to follow" (Nudzor 2009, 87) in order to identify firstly, the underpinning ideological constructions of teaching and secondly, some of the ambiguities and gaps in these constructions. There are two broad ways of analyzing text: examining manifest content through a quantitative analysis and surfacing latent content through a qualitative process (Graneheim and Lundman 2004). The analysis of manifest content on the recurrence of specific terms tends to breakdown texts and so the overall meaning can be lost. In a concise technical document such as a professional standard it is important to surface the ideological construction of key concepts. Therefore, in this study, a qualitative approach was adopted to surface the latent content.

To analyse the latent content, one of the strategies proposed by Miles and Huberman (1994) was adopted: the texts were read and re-read to identify patterns and themes and note clusters of meanings. Here the focus is not simply on the specific terms used but the way the ideas are presented including themes evident in the texts. Fairclough $(2002,24)$ proposes "one cannot properly analyse content without simultaneously analysing form, because contents are necessarily realized through form, and different content entail different forms and vice versa". Thus, in the first stage of analysis attention was paid to the design of the standards seeing each as a 'whole text' with stated purposes. In the second stage looking at content, attention was paid to identifying the codes of meaning (Cohen et al. 2007) clustered around the two recurring concepts of (1) 'teacher leadership' (2) 'practitioner enquiry'.

\section{Analysis of the Standards: Purposes}


Through the analysis, it is clear that standards are positioned as a key element in efforts to raise the quality of the teaching profession. The GTCS (n.d.) asserts that,

These revised standards support the creation of a reinvigorated approach to 21 st century teacher professionalism, recognising the importance of teacher responsibility for, and ownership of, their professional learning. The teaching profession, working in partnership with other professions, has a moral imperative to secure the best learning opportunities and experiences for all learners in Scotland.

From the first analysis, two key issues were identified:

- a number of competing purposes are evident, particularly for the SfFR and

- a significant difference exists between the declared purposes of the SfFR and that of the second standard, the SfCLPL.

In the SfFR, the regulatory function is clear: teachers are cautioned that this is "not a checklist", nevertheless, "the Professional Actions provide a focus for what needs to be done". The SfFR is designed to provide a gate-keeping function for entry into the profession and provides "a clear and concise description of the professional qualities and capabilities fully registered teachers are expected to maintain and enhance throughout their careers" (GTCS n.d.). This standard is also intended to ensure that "learners, parents, the profession itself and the wider community can have confidence" in the profession. The SfFR primarily provides a benchmark for the minimum expectation of a teacher's role, being the only standard to which a teacher can legally be held to account, used in performance management and disciplinary procedures. The inherent tension with this is that there is an expectation that meeting the SfFR extends beyond a singular event demonstrated at the end of the induction period in order to become a fully registered teacher. Teachers are expected to maintain and enhance their practice to meet changing expectations over a career. The question follows as to whether the SfFR can perform both minimum mandatory expectations and on-going aspirations.

The stated purposes of the SfCLPL are significantly different, intended to provide an aspirational framework which articulates the ways in which teachers maintain and enhance their practice through on-going professional learning: "teachers will continue to develop their expertise and experience" and "offer constructive support for teachers as they consider how they might develop their professional knowledge and skills through on-going self-evaluation and professional learning" (GTCS online). The developmental focus is the dominant theme in the SfCLPL, being a tool to help teachers "identify, plan and develop their own professional learning needs and to ensure continuing development of professional practice". The SfCLPL sets out a set of professional actions that encapsulate practices related to teacher development and so it provides a framework for on-going professional development. The standard can be used by teachers as they develop their role in "teacher leadership and leadership for learning", "actively embracing ... principles and practices of sustainability". It is also designed to be aspirational in the sense that teachers are not expected to ever reach the point where they have 'completed' this standard. This differs significantly from understandings of standards as benchmarks (Forde et al. 2015) and so in the SfCLPL there is again a tension between being an aspirational development tool that also codifies minimum expectations.

\section{Analysis of Standards: Design}

The interdependence of form and content is, as Fairclough (2002) argues, important in analysing the latent content and so the design of standards for teaching helps convey the underpinning construction of the nature of teaching and what it means to be a teacher. The design of both the SfFR and the SfCLPL presents teaching as a complex process. Both standards contain statements for:

- Professional Values and Personal Commitment

- Professional Knowledge and Understanding 


\section{- Professional Skills and Abilities}

- Professional Actions.

These standards have avoided being highly technicist, with teaching perceived not simply as a set of technical skills but instead, the different elements constructed as interdependent. Teaching is constructed as a values based process, whereby teachers draw upon bodies of knowledge and on professional skills and qualities to 'enact teaching'. These actions are focused on addressing the learning needs of "all learners", a recurring theme across both standards (Forde and Torrance forthcoming). This process is set out in Figure 1.

\section{Figure 1: Design of the Standard for Full Registration and for Career-Long Professional learning}

To this point, we have focused the analysis on the stated purposes and overall design of these sets of professional standards. We now turn our attention to the two specific concepts of teacher leadership and practitioner enquiry which have become dominant themes in the policy processes designed to bring about a reprofessionalisation of the teaching profession in Scotland. We begin with a discussion of each of these concepts by drawing on the literature.

\section{Constructs of Teacher Leadership}

Until comparatively recently, school leadership was ascribed to formal management post holders within hierarchically structured school organisations, resulting in headteacher-leader and teacherfollower binary (Crowther 1997; Murphy 2005). Accountability for progressing school improvement directives rested with headteachers. The role of teachers was focused on teaching, their field of authority and influence assigned to classrooms (Barth 1988). Indeed, before 1985, the teacher leadership theme is largely absent from mainstream literature (Lynch and Strodl 1991). More recently the concept of distributed leadership has helped to shape teacher leadership (Harris 2003) as a means of engaging teachers in decision-making. However, there are competing ideas which are not always compatible. For example, teacher leadership could be a tool to control teachers and their teaching (Blasé and Blasé 1999) especially in the delivery of externally prescribed curricular reform within new managerialist strategies (Fitzgerald and Gunter 2008) or it could be about developing teachers' agency (Frost and Harris 2003; Katzenmeyer and Moller 2001) and advocacy (Crowther et al. 2009), and to democratise schools (Gehrke 1991) through community development (Barth 2001).

Torrance and Humes (2015) identified that common to the different conceptualisations of teacher leadership is the need for school leadership to be conceptualised as 'a relationship of social influence' (Spillane and Coldren 2011, 76). Rather than through formal authority, influence exercised through "conjoint activities" (Gronn 1999) where leadership is distributed across different groups across different parts of the school (Harris 2003). The emphasis here has been more on engaging teachers in transforming schools through 'whole school' improvement efforts (Frost and Durrant 2002), exercising influence greater than the sum of the individuals (Smylie et al. 2002), developing strategic capacity to improve teaching and learning (Crowther et al. 2009). Proponents advocate that teacher leadership professionalises teaching, strengthens school organisation through developing a learning community, promotes class and school improvement through "helping teacher colleagues and facilitating school improvement" (Murphy 2005, 77). Harris and Muijs (2003, 11) elaborate on this, seeing a teacher leader as a professional 'guide' who models collegiality as a mode of work and so builds networks of human expertise and resource: a teacher leader creates support groups for staff and so enhances teachers' self esteem. At the core of this teacher leadership role is a developmental process where there is a focus on continuous learning for themselves and other teachers (Frost and Durrant 2002). There is another strand where, based on 
their pedagogic expertise, teachers are encouraged to develop a sense of agency to construct and contribute to school improvement (Day and Harris 2003). Across the literature, the dominant themes highlight this potential for teacher leadership to redefine what it means to be a teacher within a school. Furthermore, Harris and Muijs (2003) assert that collaboration between teachers has consistently been found to enhance school effectiveness. Teacher influence is exercised through relationships with peers (Frost and Durrant 2002; Day and Harris 2003; Crowther et al. 2007). Within this perspective, teacher leadership is concerned with tapping into an underutilised, "sleeping giant" resource, empowering teachers, enhancing their self-esteem and work satisfaction, increasing motivation, performance and potentially delivering higher retention levels (Katzenmeyer and Moller 2001, 2) through responsibility, mutual accountability and collaboration (Frost and Durrant 2002). Given various perspectives on teacher leadership, it is understandable that reaching consensus on an agreed definition proves problematic (Wasley 1991) and that there is conceptual confusion (Harris and Muijs 2002). However, two themes recur across a number of teacher leadership definitions: influence and pedagogic focus (York-Barr and Duke 2004; Katzenmeyer and Moller 2001) illustrated by Crowther et al.'s (2002, xvii) definition:

Teacher leadership is about action that transforms teaching and learning in a school, that ties school and community together on behalf of learning, and that advances social sustainability and quality of life for a community.

From this analysis of the literature, we have identified a number of key themes to provide a framework to examine the construction of teacher leadership in the Scottish teaching standards:

- collaboration as a way of working.

- enhancing professional development of self and other teachers

- building networks and expertise for improvement

- seeking improvement in learning, teaching and the curriculum

- exercising social influence.

\section{Teacher Leadership in the Standards}

At the beginning of each standard there are clear statements about the centrality of leadership: "All teachers should have opportunities to be leaders. They lead learning for, and with, all learners with whom they engage. They also work with and support the development of colleagues and other partners" (SfFR 2012a, 4). In both standards we can identify examples of most of the different dimensions we identified from the literature:

\section{Table 1: Dimensions of Teacher Leadership in the SfFR and the SfCLPL}

The keynote of teacher leadership in the SfFR is working collaboratively with others as a professional development process. This idea is a thread running through the Professional Values and Personal Commitment: "working collegiality with members of our education community", (1); and forming part of Professional Knowledge: "know how to work collaboratively with colleagues" (2.1.2). There are some instances where aspects of leadership form part of the skill set of all teachers: in Professional Skills and Abilities particularly in building effective working relationships and working collaboratively with colleagues: "work collaboratively to contribute to the professional learning and development of colleagues" (3.4.2). There is an emphasis on teachers knowing how to collaborate and engage with others. It might be expected that the aspect of 'seeking improvement in learning, teaching and the curriculum' would be a core attribute of teacher leadership, given that this is the standard for all registered teachers. However, this dimension is not elaborated: teachers are required to "lead learning", exercise "leadership for learning"; and should be "seeking opportunities to lead learning" (3.4.2). There is no example of 'exercising social influence' beyond building working relationships. 
The SfCLPL has the same expression of Professional Values and Personal Commitment but in the other elements of the standard, there is a far clearer focus on leadership. Here, leadership is expressed through collaboration, an essentially developmental process: "create and contribute to a collegiate culture"; and "working collaboratively across disciplines, professions and communities" (2.2). Thus teachers are expected to lead rather than just participate in a collegiate culture. The importance of teacher leadership is most evident in the set of Professional Actions: "lead and contribute to the professional learning of all colleagues including students" (3.5) and "lead and participate in collaborative professional enquiry" (3.3).

From the $S f F R$ to the $S f C L P L$ we can see a development from a nascent form of leadership. Whereas in the SfFR teachers are expected to know how, that is, have knowledge, skills and commitment; in the SfCLPL teachers are expected to practice leadership. The construction of teacher leadership is premised upon collaborative practice and this form of leadership evolves from knowledge to action and from participating and exchanging with peers to explicitly influencing others and directing activities. The more developed form of leadership in the SfCLPL remains bounded with teacher leadership, centred on the development of curriculum and pedagogy rather than in wider areas, for example, the generation of policy and building partnerships. Again though, there is no reference to exercising social influence.

\section{Constructs of Practitioner Enquiry}

Terms such as 'practitioner enquiry', 'action research' and 'teacher research' make a link between the practice of teaching and research. While these terms are used interchangeably in teaching there are some subtle differences which represent differing understandings of what it means to be a teacher. Lewin's (1946) work on groups, seeking solutions to problems in practice, is cited as the starting point for action research. In the Ford Teaching Project in the UK action research was used to develop inquiry/discovery teaching (Elliot and Adelman 1973) where importantly reflection and action were joint responsibilities of both teachers and researchers. More recently, action research has been used in university and school partnership (Baumfield and Butterworth 2007) and the UK Teaching and Learning Research Programme (Campbell 2007). An action research cycle comes from issues and questions emerging in the day-to-day practice in the classroom (Baumfield and Butterworth 2007). This approach to action research has very much dominated the literature where action research is a 'method' and so the focus is on the tools and approaches to be used (Townsend 2013).

The wider concept of teacher research has been identified as a facet of an extended professionalism (Stenhouse 1975) and more recently of a reinvigorated professionalism (Williamson and Robinson 2009). The starting point for Stenhouse was the deeply contextualized nature of teaching and he argued that proposals generated at school level need to be trialed within individual classrooms. Here, the collective nature of the process is combined with the close inspection of pupil learning within a particular context. For Stenhouse, teacher research was partly about reconceptualising what it means to be a teacher: "the outstanding characteristics of the extended professional is a capacity for autonomous professional self development through systematic self-study, through the study of work of other teachers and through the testing of ideas by classroom research procedures" (144). For Cochran-Smith and Lytle's (1993, 23-24) teacher research which is "systematic, intentional inquiry by teachers about their own school and classroom work" is the means by which teachers could contribute to the wider body of knowledge. Much of the current work goes back to CochranSmith and Lytle's search for authentic research based on and reflecting the day-to-day life in classrooms. There remain tensions around the contextualized nature of the knowledge generated through teachers researching their own setting and practice and the more exacting demands of rigour and generalisability in the production of propositional knowledge. In a more recent discussion, Cochran-Smith and Lytle $(2009,120)$ have explored the idea of "inquiry as stance" 
which embraces change strategies alongside critical and collaborative approaches to explore purposes, issues and practices. Inquiry is itself the teaching process and this resonates with Stenhouse's $(1975,156)$ argument about curriculum development: "By a research stance I mean a disposition to examine one's own practice critically and systematically".

The idea of 'inquiry as stance' has turned attention to the processes of teacher education, both initial and continuing education and the development of inquiry-based pedagogies. Reeves and Fox (2008) give a detailed account of what happens when a teacher undertakes a professional enquiry in their classroom and argue that such a process is transformative for an individual teacher, suggesting new understandings of what it means to be a teacher: "possibilities of a wider professional role that encompasses contributing ideas and supporting discussion among colleagues and others, influencing decision-making and formulating an informed position in relation to policy and practice" (28). From this review, we can identify different dimensions of the idea of "practitioner enquiry':

- systematic and intentional enquiry into problems in practice sharing knowledge with other practitioners

- contributing knowledge

- a facet of professionalism: teacher autonomy and agency

- processes of professional learning .

\section{Analysis: Practitioner Enquiry}

The expectation that all teachers will demonstrate a commitment to 'lifelong enquiry' is explicit within the set of Professional Values and Personal Commitment in each professional standard. We see a contrast in the articulation of practitioner enquiry in the two standards: in the SfFR, practitioner enquiry comes through in a number of allied practices but is specifically named in the $S f C L P L$, linking career-long professional learning with the core principles of practitioner enquiry.

\section{Table 2: Dimensions of Practitioner Enquiry in the $S f F R$ and the $S f C L P L$}

The contrast between the SfFR and SfCLPL, comes in the expectation to realise practitioner enquiry in action. The concept is $S f F R$ is more restricted: teachers are expected to "know how to engage in critical enquiry" (2.3.2). Any action is linked to a thinner version of practitioner enquiry - a questioning stance - "demonstrate an enquiring and critical approach to their professional practice" (3.4.2) or evaluation: "evaluate and adapt their classroom practice rigorously and systematically" (3.4.2.). Further, for professional learning teachers are expected to: "systematically engage with research to challenge and inform professional practice" (3.4.1).

In the SfCLPL where 'enquiry and research' is a specific item in Professional Knowledge and Professional Actions, the development is evident both in terms of moving on from 'knowing how to undertake enquiries', to being expected to "...engage in practitioner enquiry" (3.3) and "systematically investigate, analyse and evaluate the impact of practice" (2.2). Here professional enquiry approaches are part of a wider collaborative process - "lead and participate in collaborative practitioner enquiry" (3.3) - related to the improvement and the development of colleagues: "They ... will support teachers as they develop as reflective, accomplished and enquiring professionals". According to the $S f C L P L$, teachers will not just use research but will: "create knowledge to enhance, progress and lead the learning experience of all their learners" (GTCS 2012b, 4). Even in this more elaborated construction of practitioner enquiry there is a lack of any reference to one of the key components identified in the literature whereby the process of practitioner enquiry enhances teacher autonomy and agency. This idea is mentioned in the support material where teachers are described as 'being critical' and being a 'legitimate knowledge creator' but even here, the focus is 
very much on the individual teacher's practice: "Individuals who adopt this enquiring stance as the core of their professional practice will critically question their own educational beliefs, assumptions, values and practices" (GTCS online). Knowledge creation is located within a bounded space of teachers' own practice and through working collaboratively, the practice of colleagues.

\section{Discussion}

As the policy body responsible for professional regulation, the General Teaching Council for Scotland sets the standards for all teachers in Scotland. As such, the professional standards represent a policy instrument utilised both to redefine what is meant by teacher expertise and to change the profession from outwith. Sachs (2003) suggests treating standards with 'scepticism and caution' as they may become mechanistic, restricting reflective practice and encouraging conformity, encouraging competence but stifling excellence. There is then an inherent tension within standards, codifying as they do expectations of what it means to be a teacher. On the one hand, this can be seen as restrictive, focusing on narrow elements of behavioural competency as part of performance management. We should be alert to such concerns particularly where standards provide the legal definition of competence as with the SfFR (GTCS 2012a) in Scotland. On the other hand, standards can have an aspirational dimension offering alternative and more comprehensive understandings of what it means to be a teacher.

Critical in this, are the underpinning understandings around professionalism. From our analysis, the standards developed in Scotland are part of the wider strategy of modernisation. However, that modernisation is seeking to reify the position of teachers, recognising their professional expertise and agency and drawing on processes that have and continue to engage professional bodies in policy formation and implementation. Thus, the process of reprofessionalisation has not (to date) been as confrontational as modernisation projects elsewhere (Bell and Bolam 2010). Indeed in Scotland, the Professional Standards have been widely welcomed and little criticised, perhaps due to ideas about leadership and professional enquiry being perceived as non-threatening and hard to argue against. Nevertheless, the exploration of the terms 'teacher leadership' and 'practitioner enquiry' in the standards highlights the complexities of each set of concepts. Interpretations of each term vary across the international literature and policy discourse and constructions are still developing. The professional standards for teaching used in Scottish education take a specific perspective on each, making normative claims about the efficacy of teacher leadership and practitioner enquiry.

Teacher leadership is interpreted as being about encouraging teachers to see their own role as central to progressing collaborative practices. Aligning the term 'leader' with that of teacher makes possible the process of reprofessionalisation, as pedagogic practice is redefined and affirmed as being central to constructions of school leadership. The term 'teacher leadership' legitimates the role of teachers in defining practice, contributing to discussion about what makes effective practice across the school. It does so through communicating both opportunities for and responsibilities of teachers themselves, and those in formal management positions. In so doing, it raises teachers' expectations of themselves and legitimates their role as professionals through policy endorsed language. Further, it serves to mandate teachers as retaining control and direction of improvements in their practice. However, there remains the question of the scope that teachers have as leaders, to exercise the social influence that is critical to leadership. In both sets of standards this is limited to building good working relationships with colleagues, the wider school community and professional communities. In this way, the scope of leadership in the standards is bounded.

Allied to this idea of teacher leadership is the notion of practitioner enquiry. We have seen from the literature that practitioner enquiry has the potential to enable teachers to develop and contribute their expertise within their school context and potentially to the wider body of knowledge, by producing understandings based in authentic settings. However, despite the strong advocacy of 
practitioner enquiry in the SfFR, this represents a restricted model around 'know how' rather than enact. Professional actions relate more to using research and to engaging in evaluation. Perhaps most striking across both sets of standards, is the lack of an articulation of autonomy and agency as facets of practitioner enquiry that reflect the lack of a clear focus on the exercise of social influence related to teacher leadership. Though in the SfCLPL there is a reference to teachers generating knowledge, this is within a contained space where teachers "develop and apply expertise" rather than in the wider vision proposed by Cochran-Smith and Lytle (2009) of teachers contributing to wider bodies of knowledge. If this is to become a reality, then the challenges that occur in the space where teacher leadership and practitioner enquiry overlap need to be recognised and addressed, specifically the profession itself needs to ask: who owns the space where teachers' pedagogical expertise is recognised and collaborative processes are enacted?

\section{Conclusion and Implications for Continuing Teacher Education}

Internationally, standards assume a variety of purposes including regulation and compliance, through articulating definitions of acceptable practice. Standards can also have an aspirational purpose but in order for such aspirations - or workforce reform - to become a reality, the profession needs to engage with those aspirations through enhanced professional practice. This case study of the Scottish perspective serves to remind us that in the development of professional standards, teachers need to be able to interact with these texts in a meaningful manner. As we have seen, these two sets of standards provide a complex construction of teaching clearly underpinned by sets of professional values. However, complex ideas are nevertheless reduced to sets of qualities, skills and practices. The question then for continuing teacher education, is how these standards can enable teachers to enhance their practice in ways that move beyond a narrow compliance approach. We need to recognise the complexities of standards and the inherent tensions within them and so in continuing teacher education, standards cannot be constructed as simply self-evaluation and planning tools but instead, need to be treated as discursive texts, where meaning is unclear. In so doing, teachers as professionals and now promoted as experts in their practice, have the opportunity to question endorsed policy and become better informed in their practice. Further, continuing teacher education should seek to develop skills of reading and debating these standards. This is an iterative process where standards and professional learning can go hand in hand: professional learning legitimating practices associated with teacher leadership and practitioner enquiry, enabling space for this. To move beyond policy rhetoric, teachers need permission, space and tools to debate the ideas underpinning standards and to appreciate them as contested ideas, exploring ways of generating practices in their own context. Standards can help to create space and legitimacy for ideas and practices of teacher leadership and of practitioner enquiry but there is a danger for such processes to become domesticated within a process of policy implementation, where externally generated ideas, policies and strategies are presented to schools and teachers who are expected to simply take these forward. The challenge for those designing and leading continuing teacher education programmes is to ensure that the concepts of teacher leadership and practitioner enquiry are not reduced to sets of techniques to be demonstrated. Instead, these are sets of practices based on the exercise of influence and agency on the part of the teacher and have to sit at the heart of a genuine re-professionalisation of teaching.

\section{References}

(List has had author publications removed)

Australian Institute for Teaching and School Leadership (2011) Australian Professional Standards for Teaching. Australia: AITSL. 
Barth, R. S. 1988. Principals, Teachers, and School Leadership. Phi Delta Kappan, 699, no. 1: 63942.

Barth, R. S. 2001. Teacher Leader. Phi Delta Kappan, 826, no. 6: 443-49.

Baumfield, V. \& Butterworth, M. 2007. Creating and translating knowledge about teaching and learning in collaborative school-university research partnerships: an analysis of what is exchanged across the partnerships by whom and how. Teachers and Teaching 13, no. 4: 411-427.

Bell, L. \& Bolam, R. 2010. Teacher Professionalism and Continuing Professional Development: Contested concepts and their implications for school leaders. In The Principles of Educational Leadership and Management ( $2^{\text {nd }}$ Ed). T. Bush, L. Bell and D. Middleton. eds. 89-111. London: Sage.

Blasé, J. \& Blasé, J. 1999. Implementation of Shared Governance for Instructional Improvement: Principals' perspectives. Journal of Educational Administration, 37, no. 2: 476-500.

Buchanan, R. (2015) Teacher Identity and agency in an era of accountability, Teachers and Teaching: theory and practice, 21(6), 700-719.

Campbell, A. 2007. Practitioner Research. London: TLRP.

http://www.tlrp.org/capacity/rm/wt/campbell

Carr, W. K. \& Kemmis, S. 1988. Becoming critical: education, knowledge and action research. Lewes, Sussex: Falmer.

Centre of Study for Policies and Practices in Education (CEPPE), Chile (2013), Learning Standards, Teaching Standards and Standards for School Principals: A Comparative Study. Paris: OECD Publishing. http://dx.doi.org/10.1787/5k3tsjqtp90v-en

Ceulemans, C., Simons, M., \& Struyf, E. 2012. Professional standards for teacher: how do they work? An experiment in tracing standardisation in-making in teacher education. Pedagogy, Culture and Society, 20, no.1: 29-47.

Christie, D. \& Kirkwood, M. 2006. The New Standards Framework for Scottish Teachers: Facilitating or constraining reflective practice? Reflective Practice: International and Multidisciplinary Perspectives, 72, no. 2: 265-276.

Cochran-Smith, M. \& Lytle, S. L. (1993). Inside/outside: Teacher research and knowledge. Columbia: Teachers College Press.

Cochran-Smith, M. \& Lytle, S. L. 2009. Inquiry as stance: Practitioner research for the next generation. Columbia: Teachers College Press.

Cohen, L. Mannion, L. \& Morrison, K. 2007. Research Methods in Education (6 ${ }^{\text {th }}$ Ed). London: Routledge Falmer.

Crowther, F. 1997. The William Walker Oration, 1996 - Unsung Heroes: The leaders in our classrooms. Journal of Educational Administration, 35, no. 1: 5-17.

Crowther, F. Kagan, SS. Ferguson, M. \& Hann, L. 2009. Developing Teacher Leaders: How teacher leadership enhances school success $2^{\text {nd }}$ Edition. London: Sage.

Darling-Hammond, L. 1999. Reshaping Teaching Policy, Preparation and Practice. Influences of the National Board for Professional Teaching Standards. Washington: American Association of Colleges for Teacher Education.

Day, C. \& Harris, A., 2002. Teacher leadership, reflective practice, and school improvement. needs editors In K. Leithwood and P Hallinger eds. 957-977. Second international handbook of educational leadership and administration. Springer Netherlands.

Department for Education. 2011. Teachers' Standards. London: Department for Education. 
Donaldson, G. 2011. Teaching Scotland's Future: Report of a review of teacher education in Scotland. Edinburgh: Scottish Government.

Education Council (2013) Practising Teacher Criteria, New Zealand: Education Council.

Elliot, J. \& Adelman, C. 1973. Reflecting where the action is: The design of the Ford Teaching project. Education for Teaching, 9, no 2: 8-20.

Fairclough, N. 2002. Discourse and Text. In Critical Discourse Analysis: Critical concepts in linguistics. M. Toolan, ed. London: Routledge, 23-49.

Fenwick, T.J. (2010) (un)Doing standards in education with actor- network theory, Journal of Education Policy, 25, no. 2, 117-133.

Fitzgerald, \& Gunter, H. 2008. Contesting the Orthodoxy of Teacher Leadership. International Journal of Leadership in Educational, 11, no. 4: 331-340.

Forde, C., McMahon, M., Hamilton, G. \& Murray, R. 2015. Professional Standards for Teaching in Scotland: Sustaining professional learning. Professional Development in Education, Vol. 41, forthcoming.

Forde, C. \& Torrance, D. forthcoming. Changing Expectations and Experiences of Headship in Scotland. International Studies in Educational Administration. Special Issue on an international perspective of the changing nature of school principals' work.

Frost, D. \& Durrant, J. 2002. Teachers as Leaders: Exploring the impact of teacher-led development work. School Leadership and Management, 22, no. 3: 143-61.

Frost, D. \& Harris, A. 2003. Teacher Leadership: Towards a research agenda. Cambridge Journal of Education, 33, no. 3: 479-498.

Gehrke, N. 1991. Developing Teachers' Leadership Skills. Washington, DC: ERIC. Retrieved ED330691, www.askeric.org.

General Teaching Council for Scotland. 2011. Revision of the Standards: Working group guidelines. Edinburgh: GTCS.

General Teaching Council for Scotland. 2012a. The Standards for Registration. Edinburgh: General Teaching Council for Scotland.

General Teaching Council for Scotland. 2012b. The Standard for Career-Long Professional Learning. Edinburgh: General Teaching Council for Scotland.

General Teaching Council for Scotland. 2012c. The Standards for Leadership and Management. Edinburgh: General Teaching Council for Scotland.

General Teaching Council n.d.. Uses for Standards. Edinburgh GTCS

http://www.gtcs.org.uk/standards/uses-for-professional-standards.aspx

Graneheim, U. H., \& Lundman, B. 2004. Qualitative Content Analysis in Nursing Research: Concepts, procedures and measures to achieve trustworthiness. Nurse Education Today, 24, no.2: 105-112.

Gronn, P. 1999. Distributed properties: A new architecture for leadership. Educational Management, Administration and Leadership, 28, no.3: 317-337.

Gronn, P. 2000. Designer Leadership: The Emerging Global Adoption of Preparation Standards. Journal of School Leadership 12, no.5: 552-578.

Harris, A. 2003. Teacher Leadership and School Improvement. In Effective Leadership for School Improvement Harris, A., Day, C., Hopkins, D., Hadfield, M. Hargreaves, A. \& Chapman, C. eds. 72-83. London: Routledge Falmer. 
Harris, A. \& Mujis, D. 2003. Teacher Leadership: Principles and practice. Nottingham: National College for School Leadership.

Hoyle, E. 1995. Professional Knowledge and Practice, London: Routledge.

Johnston, D. \& MacKenzie, M.L. 2003. The Politics of Scottish Education. In Bryce, T.G.K. \& Humes, W.M. (Eds.) Scottish Education - Second Edition: Post-Devolution. Edinburgh: Edinburgh University Press, 86-97.

Katzenmeyer, M., \& Moller, G. 2001. Awakening The Sleeping Giant: Helping teachers develop as leaders. Thousand Oaks, CA: Corwin Press.

Kennedy, A. 2005. Models of continuing professional development: a framework for analysis. Journal of In-service Education, 31, no. 2: 235-250.

Kleinhenz, E. \& Ingvarson, L. 2007. Standards for Teaching: Theoretical underpinnings and applications. Australia: Australian Council for Educational Research.

http://research.aceredu.au/teaching_standards/1

Lewin, K. 1946. Action Research and Minority Problems. Journal of Social Issues, 2, no. 4, 34-46.

Lynch, M. \& Strodl, P. 1991. Teacher Leadership: Preliminary development of a questionnaire. Paper presented at the annual conference of the Eastern Educational Research Association, Boston, MA.

McCormac, G. 2011. Advancing Professionalism in Teaching: A review of teacher employment in Scotland. Edinburgh: Scottish Government.

Miles, M.B. \& Huberman, A.M. 1994. Qualitative Data Analysis: An expanded sourcebook.

London: Sage Publications.

Murphy, J. 2005. Connecting Teacher Leadership and School Improvement. Thousand Oaks, CA: Corwin Press.

Nudzor, H. 2009. What is "Policy", a Problem-solving Definition or a Process Conceptualization? Educational Futures, 2, no. 1: 85-96.

O’Brien, J. (2011) Continuing professional development for Scottish teachers: tensions in policy and practice, Professional Development in Education, 37, no.5: 777-792.

Organisation for Economic Co-operation and Development (2012) Equity and Quality in Education: Supporting Disadvantaged Students and Schools, Paris: OECD.

Organisation for Economic Co-operation and Development (2015) Education Policy Outlook 2015: Making Reforms Happen, Paris: OECD.

Reeves, J. \& Fox, A. Eds. 2008. Practice Based Learning: Developing Excellence in Teaching. Edinburgh: Dunedin Academic Press.

Reeves, J., Forde, C., Casteel, V. \& Lynas, R. 1998. Developing a Model of Practice: Designing a framework for the professional development of school leaders and managers. School Leadership and Management, 18, no.2: 185-196.

Sachs, J. 2003. Teacher Professional Standards: Controlling or developing teachers? Teacher and Teaching: Theory and Practice, 9, no. 2: 175-86.

Scottish Executive Education Department. 2001. A Teaching Profession for the $21^{\text {st }}$ Century: Agreement reached following recommendations made in the McCrone Report. Edinburgh: Scottish Executive.

Scottish Parliament. 2011. The Public Services Reform (General Teaching Council for Scotland) Order 2011. http://www.legislation.gov.uk/ssi/2011/215/contents/made 
Silva, D.Y., Gimbert, B. \& Nolan, J., 2000. Sliding the doors: Locking and unlocking possibilities for teacher leadership. Teachers College Record, 102, no. 4: 779-804.

Smylie, M. A., Conley, S. \& Marks, H.M. 2002. Exploring New Approaches to Teacher Leadership for School Improvement. Yearbook of the National Society for the Study of Education, 1011, 162188.

Spillane, J. P. \& Coldren, A. F. 2011. Diagnosis and Design for School Improvement. New York: Teachers College Press.

Stenhouse, L. 1975. An Introduction to Curriculum Research and Development. London: Heinemann.

Stillman, J. \& Anderson, L. 2015. From accommodation to appropriation: teaching, identity, and authorship in a tightly coupled policy context, Teachers and Teaching: Theory and Practice, 21(6), 720-744.

Taylor, S. 1997. Critical Policy Analysis: Exploring contexts, texts and consequences. Discourse: Studies in the Cultural Politics of Education, 18, no. 1: 23-35.

Torrance, D., \& Humes, W. 2015. The Shifting Discourses of Educational Leadership: International trends and Scotland's response. Educational Management, Administration and Leadership, Vol. 43(5): 792-810.

Townsend, A. 2013. Action Research: The Challenges of Understanding and Changing Practice, Maidenhead, Berkshire: Open University Press.

Tuinamuana, K. 2011. Teacher Professional Standards, Accountability, and Ideology: Alternative Discourses. Australian Journal of Teacher Education, 36, no.12: 72-82.

Wasley, P. A. 1991. Teachers Who Lead: The rhetoric of reform and realities of practice. New York: Teachers College Press.

Williamson, Z., \& Robinson, G. 2009. 'Challenge', 'Freedom', 'Change': An emerging language of activism from Chartered Teachers? Professional Development in Education, 35, no.1, 43-61.

York-Barr, J. \& Duke, K. 2004. What Do We Know About Teacher Leadership? Findings from two decades of scholarship. Review of Educational Research, 74, no.3: 255-316. 